\title{
Profile distribution of available nutrients in a Vertisol and Inceptisol as influenced by irrigated and rainfed cotton crops
}

\author{
S. M. Bambhaneeya $₫$ \\ College of Agriculture, Navsari Agricultural University, Campus Bharuch, Gujarat \\ N. H. Garaniya \\ College of Agriculture, Navsari Agricultural University, Campus Bharuch, Gujarat \\ K. H. Patel \\ College of Agriculture, Navsari Agricultural University, Campus Bharuch, Gujarat \\ Vaishali Surve \\ College of Agriculture, Navsari Agricultural University, Campus Bharuch, Gujarat
}

\begin{tabular}{|c|c|}
\hline ARTICLE INFO & ABSTRACT \\
\hline $\begin{array}{l}\text { Received : } 06 \text { June } 2021 \\
\text { Revised : } 31 \text { August } 2021 \\
\text { Accepted : } 14 \text { September } 2021 \\
\text { Available online: } 9 \text { December } 2021 \\
\text { Key Words: } \\
\text { Cotton } \\
\text { Nutrients } \\
\text { Vertisol } \\
\text { Inceptisol } \\
\text { Irrigated } \\
\text { Rainfed }\end{array}$ & 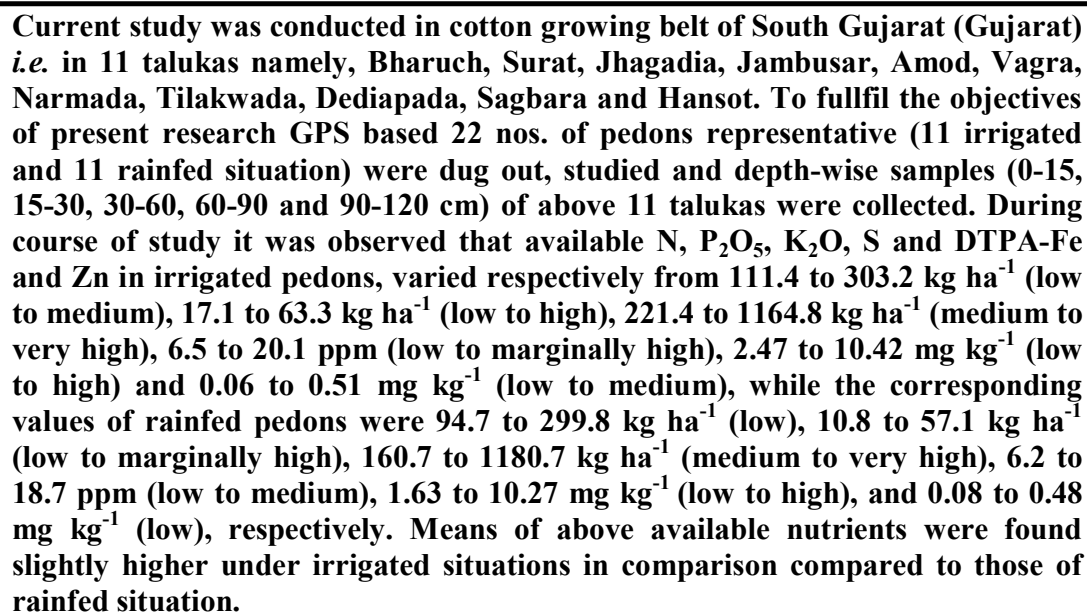 \\
\hline
\end{tabular}

\section{Introduction}

Cotton is most important fiber crop ('queen of time) could lead to development of soil great fibres') which plays very important role in groups. Coming to South Gujarat condition and that economic and social affairs of people, especially in India. This 'white gold' (cotton) is one of the most important cash crops of Gujarat state. The idea of study of soil profile i.e. the whole mass extending from surface down to parent material from which the soil is formed, was introduced by Dokuchaiev (1886). He was stated soil as a natural body composed of mineral and organic constitutes, having a definite genesis and a distinct nature of its own. Again, Jenny (1941) postulated that specific combination of soil forming pedogenic processes (governed by action of various soil forming factors like climate, organism, parent material, relief and too in cotton growing belt of South Gujarat encompassing 11 talukas (Bharuch, Jhagadia, Jambusar, Amod, Vagra, Hansot, Surat, Narmada, Dediapada, Tilakwada and Sagbara), it is obvious that within the area of area of 11 talukas soils in their quality and aggregate size classes would vary from one site to another site due to differences in organic and inorganic inputs, tillage practices along with other external inputs over the years as a results of differences in cotton canopy coverage, leaf litter fall, root bulk volume, irrigation as well as rainfall situation. Any research work towards enhancement of cotton crop productivity or soil quality on which

Corresponding author E-mail: suresh10soilchemist@yahoo.in

Doi: https://doi.org/10.36953/ECJ.2021.22323

This work is licensed under Attribution-Non Commercial 4.0 International (CC BY-NC 4.0)

(C) ASEA 
it survives would be of paramount importance. A research topic, thus, was chosen on cotton growing soils of South Gujarat. Cotton cultivation in Gujarat is done on various soils right from sandy soil of Kutch, the alluvial soil of Ahmadabad and Kheda districts to the black and black cotton soils of Central, Southern and Saurashtra regions. As productivity of both rainfed and irrigated cotton crops largely depends on the soil characteristics under a specific set of climate, ignorance of soilsite requirement of a particular crop leads to the sub-optimal yield or complete failure of the crop. Due to continuous cotton cultivation, soils under irrigated and rainfed system may differ/ or affect soil properties which may modify nutrients content and their availability to crops, so analysis of soil properties may have significant importance in understanding proper nutrient management practices. Under these contexts, an attempt has been made to generate information on soil nutrients status in irrigated and rainfed situations in cotton growing areas of South Gujarat in order to future management of these soils for higher cotton yield.

\section{Material and Methods Overview of study area}

South Gujarat in compassing eleven talukas are distributed in three districts of South Gujarat namely Bharuch $(21.30$ to $22.00 \mathrm{~N}, 72.450$ to $73.150 \mathrm{E})$, Surat $\left(20^{\circ} 10^{\prime} 596^{\prime \prime} \mathrm{N}, 072^{\circ} 52^{\prime} 638^{\prime \prime} \mathrm{E}\right)$ and Narmada $\left(21^{\circ} 52^{\prime} 028^{\prime \prime} \mathrm{N}, 073^{\circ} 30^{\prime} 035^{\prime \prime} \mathrm{E}\right)$. Major soils are clayey in texture. The area comes under subtropical climate with semi arid conditions. The annual rainfall varies in these talukas from 700 to $950 \mathrm{~mm}$. However, Surat city receives little more rainfall i.e. about $1200 \mathrm{~mm}$. Distribution of rainfall is not uniform. Moreover, soils fertility status is also medium to poor and a result, yield of cotton (desi or hybrid or $B t$ ) crop is not optimum and varies widely from talukas to talukas. Thus, it is essential to analyze the soil samples chemically so as to have analytical results on parameters like nitrogen, phosphorus, potassium, sulphur, iron and zinc in order to take appropriate management practices for improving cotton yield.

\section{Soil sampling and analysis}

22 nos. of soil profiles (11 from irrigated and 11 from rainfed situations) were excavated at cotton growing areas of 11 talukas (1 representative profile from rainfed area and 1 representative profile from irrigated area in each taluka). All the profiles were excavated upto $120 \mathrm{~cm}$ soil depth. From each profile, depth wise $(0-15,15-30,30-60$, 60-90 and 90-120 cm) five samples were collected using GPS for analysis. All the collected soil samples were air dried, processed and analyzed for above available nutrients following standard methods (Jackson, 1973). Soil N was determined by using alkaline potassium permanganate method (Subbiah and Asija, 1956), phosphorus were determined by extracting soil with $0.5 \mathrm{M} \mathrm{NaHCO}_{3}$ at $\mathrm{pH} 8.5$ and determining $\mathrm{P}$ from the filtrate by spectrometric method (Olsen et al. 1954), potassium was determined by flame photometer by using normal neutral ammonium acetate (1N NH4OAc adjusting $\mathrm{pH} 7.0$ as extractant) as described by Jackson (1973) and available sulphur was estimated by using 0.15 per cent $\mathrm{CaCl}_{2}$ solution as extractant following the method as narrated by Williams and Steinbergs (1959). DTPA- Zn was determined by using Atomic Absorption Spectrophotometer as per the procedure described by Lindsay and Norvell (1978).

\section{Results and Discussion Available nitrogen (N)}

Available $\mathrm{N}$ from all soil depths of irrigated profiles presented in Table 1 revealed that the available $\mathrm{N}$ in $\mathrm{P} 1, \mathrm{P} 3, \mathrm{P} 5, \mathrm{P} 7, \mathrm{P} 9, \mathrm{P} 11, \mathrm{P} 13, \mathrm{P} 15$, $\mathrm{P} 17, \mathrm{P} 19$ and P21, respectively from Maktampur, Achhaliya, Tancha, Vagra, Manglad, Hansot, Narmada, Nighat, Sagbara, Uchad and Athwa, was 'low to medium', depicting wide range from 111.4 to $282.0,173.1$ to $238.3,188.8$ to $230.8,186.9$ to $242.1,163.1$ to $225.8,117.3$ to $222.4,154.2$ to $286.8,161.8$ to $219.5,143.0$ to $201.3,165.6$ to 303.2 and 139.7 to $285.0 \mathrm{~kg} \mathrm{ha}^{-1}$, respectively with corresponding mean values of $229.2,214.3,212.7$, $214.0,202.5,155.8,194.9,195.9,165.7,212.9$ and $222.5 \mathrm{~kg} \mathrm{ha}^{-1}$, respectively. Mean soil available N in all the profiles, though varied appreciably from profile to profile, yet exhibited low value. The magnitude of available $\mathrm{N}$ was found higher in surface soils $(0-15 \mathrm{~cm})$ as compared to other depths of profiles and the same gradually decreased with depth, barring P3, P13, P15 and P19 showing somewhat irregular trend with depths. As SOC content in surface soils was high, surface soils exhibited higher available $\mathrm{N}$ content through mineralization processes due to microbial activity. 
At deeper soil layers, lower available $\mathrm{N}$ status might be associated with low content of SOC coupled with low mineralization processes due to low microbial population indicating low productivity potential. The reason for irregular trends of these profiles might be due to churning processes of Vertisols / Vertic Inceptisols having swelling shrinkage clays with deep and wide cracks. However, P1 had the highest $\left(229.2 \mathrm{~kg} \mathrm{ha}^{-1}\right)$ mean available $\mathrm{N}$ content while $\mathrm{P} 11$ exhibited the lowest mean $\left(155.8 \mathrm{~kg} \mathrm{ha}^{-1}\right)$ available $\mathrm{N}$ content. Based on profiles mean available $\mathrm{N}$ content, the irrigated profiles can be placed in the following descending order: $\mathrm{P} 1>\mathrm{P} 21>\mathrm{P} 3>\mathrm{P} 7>\mathrm{P} 19>\mathrm{P} 5>$ $\mathrm{P} 9>\mathrm{P} 15>\mathrm{P} 13>\mathrm{P} 17>\mathrm{P} 11$. 'Low to medium' available $\mathrm{N}$ content in soils of all the irrigated profiles might be due ascribed to several factors, such as low organic carbon (due to sub-optimal vegetations), high soil $\mathrm{pH}$ and ESP favouring higher volatilization losses, reduced nitrification and activity of $\mathrm{N}$ fixing bacteria and this fact was supported by Kumar and Haroon (2013) and Bhaskar (2015) and Prabhavati et al. (2015).

However, in rainfed profiles (Table 1) of $\mathrm{P} 2, \mathrm{P} 4$, P6, P8, P10, P12, P14, P16, P18, P20 and P22 (from Bharuch, Jhagadia, Amod, Gandhar, Jambusar, Hansot, Nandod, Dadiapada, Panch Pipri, Tilakwada and Panas, respectively) the status of available $\mathrm{N}$ was 'low to medium' ranging from 147.4 to $203.8,171.2$ to $244.0,174.2$ to 227.1 , 186.9 to $225.8,160.6$ to $249.6,98.5$ to $176.9,157.4$ to $210.1,146.1$ to $207.6,94.7$ to $186.9,116.0$ to 299.8 and 145.2 to $250.9 \mathrm{~kg} \mathrm{ha}^{-1}$, respectively with corresponding mean values of 167.6, 207.6, 208.7, 208.5, 199.8, 144.1, 175.6, 192.8, 144.1, 194.2 and $198.5 \mathrm{~kg} \mathrm{ha}^{-1}$, respectively. It was observed that P6 recorded the highest $\left(208.7 \mathrm{~kg} \mathrm{ha}^{-1}\right)$ available $\mathrm{N}$ content and P18 showed the lowest mean $(144.1 \mathrm{~kg}$ $\mathrm{ha}^{-1}$ ) one. Thus, the rainfed profiles can be placed in the following descending order: $\mathrm{P} 6>\mathrm{P} 8>\mathrm{P} 4>$ $\mathrm{P} 10>\mathrm{P} 22>\mathrm{P} 20>\mathrm{P} 8>\mathrm{P} 14>\mathrm{P} 2>\mathrm{P} 12>\mathrm{P} 18$ with respect to mean available $\mathrm{N}$ content. Like irrigated profiles, the available $\mathrm{N}$ content was more in surface soils and the values decreased down the profile except in few (P2, P4, P6, P16 and P18) which showed irregular trend with depths which might be due to the same reason as described above. The results clearly indicated that $\mathrm{N}$ management particularly in rainfed situation is a must for improving available $\mathrm{N}$ status and ultimately the yield of cotton. Thus, in soils with 'low to medium' N, more organic matters / manures should be applied vis a vis activity of soil microbes to be enhanced as judicious measures under both the situations apart from regular inorganic Nfertilizer schedule as per recommendations in order to obtain higher available soil $\mathrm{N}$ status and thereby higher yield of cotton ultimately. Mean available N status of irrigated profiles together, was higher as compared to that of rainfed profiles. Reason for higher mean available $\mathrm{N}$ in irrigated profiles might be ascribed to high native SOC from higher vegetative cover and higher degree of mineralization resulting in higher mean available $\mathrm{N}$ as compared to rainfed situation. Paramasivan and Jawahar (2014), Nagesh and Mohamad (2014) and Kumar (2017) they are also found that irrigated soils under cotton crops of Bharuch district contained higher available $\mathrm{N}$ as compared to rainfed soils which he opined due to more organic matter, better crop management practices inclusive of fertilizer application.

\section{Available phosphorus $\left(\mathrm{P}_{2} \mathrm{O}_{5}\right)$}

Available P2O5 from all soil depths of irrigated profiles presented in Table 1 revealed that the available $\mathrm{P}_{2} \mathrm{O}_{5}$ in $\mathrm{P} 1, \mathrm{P} 3, \mathrm{P} 5, \mathrm{P} 7, \mathrm{P} 9, \mathrm{P} 11, \mathrm{P} 13$, $\mathrm{P} 15, \mathrm{P} 17, \mathrm{P} 19$ and P21, was 'low to high', depicting wide range from 17.4 to $79.4,17.4$ to $33.5,21.0$ to $50.1,24.8$ to $45.9,17.4$ to $26.1,26.1$ to $63.3,24.8$ to $38.5,17.1$ to $24.5,17.4$ to $35.4,18.5$ to 38.5 and 24.3 to $38.4 \mathrm{~kg} \mathrm{ha}^{-1}$, respectively with corresponding mean values of, $46.5,28.1,38.5$, $35.4,22.1,39.2,30.4,20.2,24.2,27.7$ and $30.9 \mathrm{~kg}$ $\mathrm{ha}^{-1}$, respectively. However, P1 had the highest $\left(46.5 \mathrm{~kg} \mathrm{ha}^{-1}\right)$ mean available $\mathrm{P}_{2} \mathrm{O}_{5}$ content, while P15 exhibited the lowest mean (20.2 $\left.\mathrm{kg} \mathrm{ha}^{-1}\right)$ available $\mathrm{P}_{2} \mathrm{O}_{5}$. Based on profile mean available $\mathrm{P}_{2} \mathrm{O}_{5}$ content, the irrigated profiles can be placed in the following descending order: P1 $>$ P11 $>$ P5 $>$ P7 > P21 > P13 > P3 > P19 > P17 > P9 > P15. Available $\mathrm{P}_{2} \mathrm{O}_{5}$ decreased with depth in major soil profiles. However, P1, P3, P9 and P13 did not follow any definite trend with respect to available $\mathrm{P}_{2} \mathrm{O}_{5}$. The available $\mathrm{P}_{2} \mathrm{O}_{5}$ was higher in surface soils than sub surfaces which might be due to the $\mathrm{pH}$ of surface soils in close vicinity of 7.0, whereas subsurface soils possessed comparatively higher $\mathrm{pH}$. Further, supplementation of fertilizers, organic 
Table 1: Available nutrient status of profile soil under cotton growing areas

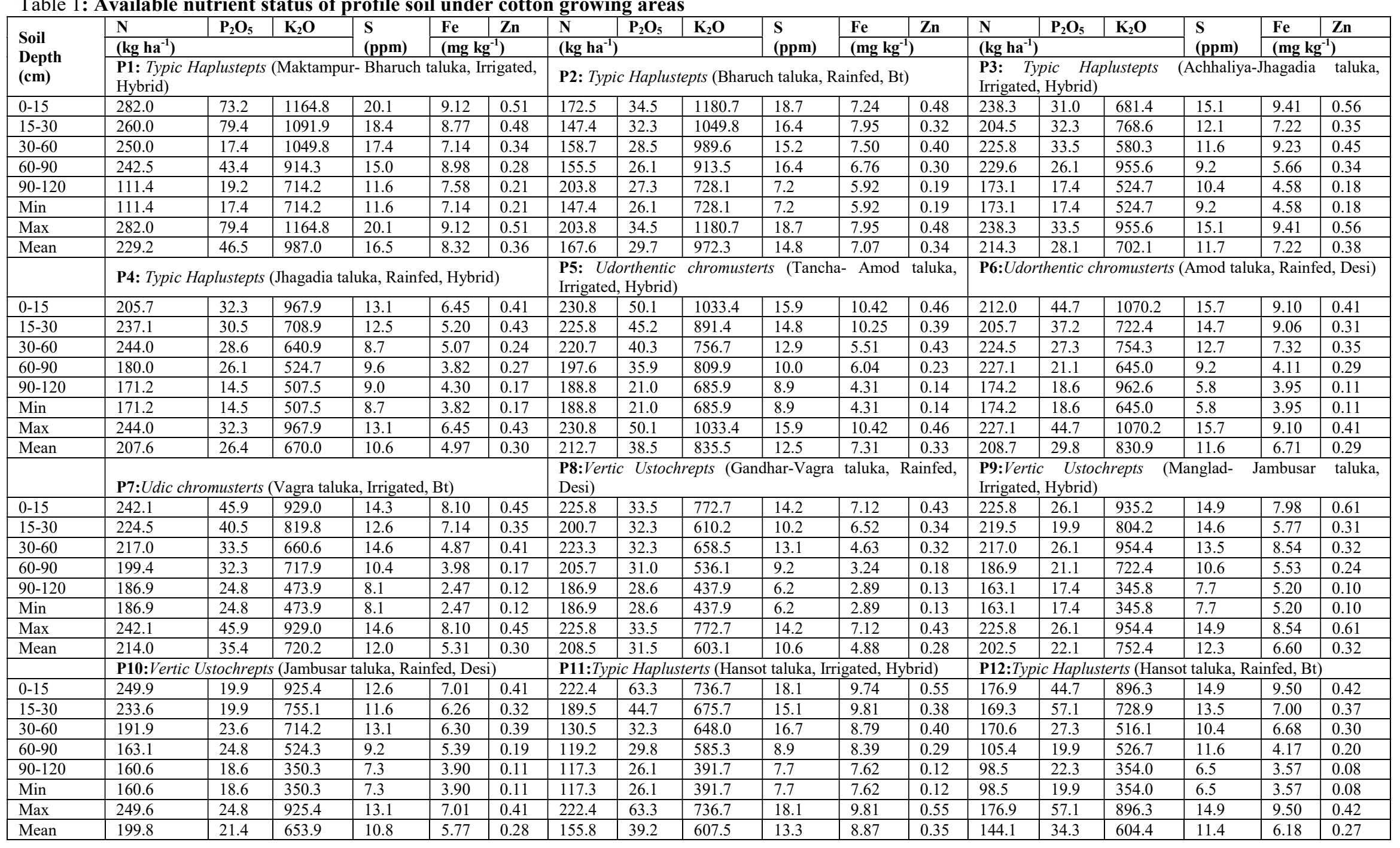


Table 1 Continue....... Available nutrient status of profile soil under cotton growing areas

\begin{tabular}{|c|c|c|c|c|c|c|c|c|c|c|c|c|c|c|c|c|c|c|}
\hline \multirow{3}{*}{$\begin{array}{l}\text { Soil depth } \\
\text { (cm) }\end{array}$} & $\mathbf{N}$ & $\mathbf{P} \mathbf{O}_{-}$ & $\mathrm{K} O$ & \multirow{2}{*}{$\begin{array}{l}\text { S } \\
(\mathbf{p p m})\end{array}$} & $\mathrm{Fe}$ & $\mathbf{Z n}$ & $\mathbf{N}$ & $\mathrm{P}_{2} \mathrm{O}_{5}$ & $\mathbf{K}_{2} \mathbf{O}$ & \multirow{2}{*}{$\begin{array}{l}\text { S } \\
(\text { ppm) }\end{array}$} & $\mathbf{F e}$ & $\mathbf{Z n}$ & $\mathbf{N}$ & $\mathbf{P}_{2} \mathbf{O}_{5}$ & $\mathrm{~K}_{2} \mathrm{O}$ & \multirow{2}{*}{$\begin{array}{l}\text { S } \\
(\mathbf{p p m})\end{array}$} & \multirow{2}{*}{\multicolumn{2}{|c|}{\begin{tabular}{l|l}
$\mathrm{Fe}$ & $\mathrm{Zn}$ \\
\multicolumn{2}{|c|}{$\left(\mathrm{mg} \mathrm{kg}^{-1}\right)$}
\end{tabular}}} \\
\hline & (kg ha' & 1205 & $N_{2} \mathrm{O}$ & & \multicolumn{2}{|c|}{$\left(\mathrm{mg} \mathrm{kg}^{-1}\right)$} & \multicolumn{3}{|c|}{$\left(\mathrm{kg} \mathrm{ha}^{-1}\right)$} & & \multicolumn{2}{|c|}{$\left(\mathrm{mg} \mathrm{kg}^{-1}\right)$} & \multicolumn{3}{|c|}{$\left(\mathrm{kg} \mathrm{ha}^{-1}\right)$} & & & \\
\hline & \multicolumn{6}{|c|}{ taluka, Irrigated, Hybrid) } & \multicolumn{6}{|c|}{$\begin{array}{l}\text { P14:Typic Ustorthents (Nandod- Narmada taluka, } \\
\text { Rainfed, Desi) }\end{array}$} & \multicolumn{6}{|c|}{$\begin{array}{l}\text { P15:Vertic Ustochrepts (Nighat- Dadiapada taluka } \\
\text { Irrigated, Hybrid) }\end{array}$} \\
\hline $0-15$ & 286.8 & 31.0 & 760.4 & 11.2 & 6.92 & 0.42 & 210.9 & 37.2 & 627.0 & 10.2 & 5.21 & 0.40 & 210.5 & 24.5 & 620.5 & 13.2 & 8.59 & 0.45 \\
\hline $15-30$ & 163.1 & 32.3 & 638.9 & 10.2 & 6.15 & 0.28 & 163.1 & 24.8 & 560.2 & 10.0 & 5.50 & 0.29 & 200.7 & 23.6 & 527.1 & 12.9 & 5.15 & 0.43 \\
\hline $30-60$ & 210.1 & 38.5 & 584.5 & 8.7 & 7.89 & 0.31 & 186.1 & 19.9 & 552.1 & 9.8 & 5.37 & 0.20 & 219.5 & 17.4 & 510.4 & 12.7 & 4.03 & 0.13 \\
\hline $60-90$ & 160.6 & 25.4 & 300.4 & 9.4 & 5.27 & 0.20 & 160.6 & 39.7 & 519.4 & 8.9 & 5.13 & 0.26 & 186.9 & 18.6 & 296.3 & 9.2 & 4.25 & 0.16 \\
\hline $90-120$ & 154.2 & 24.8 & 251.3 & 6.9 & 4.31 & 0.14 & 157.4 & 18.6 & 270.5 & 9.9 & 3.18 & 0.12 & 161.8 & 17.1 & 266.8 & 6.5 & 4.01 & 0.06 \\
\hline Min & 154.2 & 24.8 & 251.3 & 6.9 & 4.31 & 0.14 & 157.4 & 18.6 & 270.5 & 8.9 & 3.18 & 0.12 & 161.8 & 17.1 & 266.8 & 6.5 & 4.01 & 0.06 \\
\hline Max & 286.8 & 38.5 & 760.4 & 11.2 & 7.89 & 0.42 & 210.1 & 39.7 & 627.0 & 10.2 & 5.50 & 0.40 & 219.5 & 24.5 & 620.5 & 13.2 & 8.59 & $\begin{array}{l}0.45 \\
\end{array}$ \\
\hline \multirow[t]{2}{*}{ Mean } & 194.9 & 30.4 & 507.1 & 9.3 & 6.11 & 0.27 & 175.6 & 28.1 & 505.8 & 9.8 & 4.88 & 0.25 & 195.9 & 20.2 & 444.2 & 10.9 & 5.21 & 0.25 \\
\hline & \multicolumn{6}{|c|}{ P16:Vertic Ustochrepts (Dadiapada, Rainfed, Desi) } & \multicolumn{6}{|c|}{ P17:Vertic Ustochrepts (Sagbara taluka, Irrigated, Bt) } & \multicolumn{6}{|c|}{$\begin{array}{l}\text { P18:Vertic Ustochrepts (Panch Pipri- Sagbara taluka, } \\
\text { Rainfed, Desi) }\end{array}$} \\
\hline $0-15$ & 207.9 & 24.8 & 567.7 & 10.1 & 4.71 & 0.43 & 201.3 & 35.4 & 681.4 & 10.2 & 7.61 & 0.40 & 186.9 & 27.5 & 516.1 & 9.8 & 6.26 & 0.35 \\
\hline $15-30$ & 200.7 & 23.6 & 550.1 & 9.8 & 4.55 & 0.24 & 163.7 & 28.6 & 545.1 & 10.1 & 7.58 & 0.24 & 174.4 & 26.2 & 548.8 & 8.9 & 6.12 & 0.21 \\
\hline $30-60$ & 146.1 & 20.4 & 507.5 & 8.9 & 4.61 & 0.18 & 157.4 & 20.8 & 473.1 & 9.8 & 4.74 & 0.30 & 163.1 & 29.8 & 500.5 & 9.5 & 6.21 & 0.24 \\
\hline $60-90$ & 207.6 & 15.7 & 393.6 & 7.9 & 4.55 & 0.20 & 163.1 & 18.9 & 315.5 & 8.9 & 4.04 & 0.15 & $\begin{array}{l}101.3 \\
\end{array}$ & 19.9 & 302.8 & 8.5 & 3.97 & 0.12 \\
\hline $90-120$ & 202.6 & 12.4 & 160.7 & 9.4 & 2.66 & 0.08 & 143.0 & 17.4 & 221.4 & 8.8 & 3.50 & 0.07 & 94.7 & 15.8 & 240.2 & 6.4 & 3.40 & 0.13 \\
\hline Min & 146.1 & 12.4 & 160.7 & 7.9 & 2.66 & 0.08 & \begin{tabular}{|l|l|}
143.0 \\
\end{tabular} & $\begin{array}{l}17.4 \\
\end{array}$ & 221.4 & 8.8 & 3.50 & 0.07 & 94.7 & 15.8 & 240.2 & 6.4 & 3.40 & $\begin{array}{l}0.12 \\
\end{array}$ \\
\hline Max & 207.6 & 24.8 & 567.7 & 10.1 & 4.71 & 0.43 & 201.3 & 35.4 & 681.4 & 10.2 & 7.61 & 0.40 & 186.9 & 29.8 & 548.8 & 9.8 & 6.26 & $\begin{array}{l}\mathbf{0 . 3 5} \\
\end{array}$ \\
\hline \multirow[t]{2}{*}{ Mean } & 192.8 & 19.4 & 435.9 & 9.2 & 4.21 & 0.23 & 165.7 & 24.2 & 447.3 & 9.6 & 5.49 & 0.23 & 144.1 & 23.8 & 421.7 & 8.6 & 5.19 & 0.21 \\
\hline & \multicolumn{6}{|c|}{ P19:Typic Haplusterts (Uchad-Tilakwada taluka, Irrigated, Bt) } & \multicolumn{6}{|c|}{$\begin{array}{l}\text { P20:Typic Haplusterts (Tilakwada taluka, Rainfed, } \\
\text { Desi) }\end{array}$} & \multicolumn{6}{|c|}{$\begin{array}{l}\text { P21:Typic Haplustepts (Athwa- Surat taluka, Irrigated, } \\
\text { Hybrid) }\end{array}$} \\
\hline $0-15$ & 303.2 & 38.5 & 705.2 & 10.9 & 9.40 & 0.48 & 299.8 & 22.3 & 499.3 & 10.8 & 5.08 & 0.44 & 285.0 & 38.4 & 785.8 & 19.7 & 10.25 & 0.51 \\
\hline $15-30$ & 199.4 & 33.5 & 751.4 & 8.7 & 4.12 & 0.25 & 225.8 & 21.1 & 331.9 & 9.8 & 5.27 & 0.34 & 273.8 & 32.5 & 622.1 & 16.6 & 8.95 & 0.41 \\
\hline $30-60$ & 165.6 & 25.4 & 464.9 & 10.5 & 4.32 & 0.29 & 202.0 & 19.9 & 466.6 & 7.9 & 5.50 & 0.14 & 213.4 & 31.0 & 499.7 & 12.8 & 5.22 & 0.43 \\
\hline $60-90$ & 206.3 & 22.4 & 493.6 & 8.9 & 4.31 & 0.24 & 127.3 & 13.7 & 294.7 & 7.1 & 3.59 & 0.08 & 200.8 & 28.5 & 448.6 & 11.9 & 6.89 & 0.12 \\
\hline $90-120$ & 190.0 & 18.5 & 284.0 & 7.8 & 4.26 & 0.11 & 116.0 & 10.8 & 250.9 & 6.7 & 1.63 & 0.09 & 139.7 & 24.3 & 304.1 & 9.5 & 4.02 & 0.07 \\
\hline Min & 165.6 & 18.5 & 284.0 & 7.8 & 4.12 & 0.11 & 116.0 & 10.8 & 250.9 & 6.7 & 1.63 & $\mathbf{0 . 0 8}$ & 139.7 & 24.3 & 304.1 & 9.5 & 4.02 & $\mathbf{0 . 0 7}$ \\
\hline Max & \begin{tabular}{|l|}
303.2 \\
\end{tabular} & \begin{tabular}{|l|}
38.5 \\
\end{tabular} & $\begin{array}{l}751.4 \\
\end{array}$ & 10.9 & 9.40 & 0.48 & \begin{tabular}{|l|}
299.8 \\
\end{tabular} & 22.3 & \begin{tabular}{|c|}
499.3 \\
\end{tabular} & \begin{tabular}{|l|}
10.8 \\
\end{tabular} & 5.50 & 0.44 & 285.0 & \begin{tabular}{|l|}
38.4 \\
\end{tabular} & \begin{tabular}{|l|}
785.8 \\
\end{tabular} & 19.7 & 10.25 & \begin{tabular}{c|c|}
0.51 \\
\end{tabular} \\
\hline \multirow[t]{2}{*}{ Mean } & 212.9 & 27.7 & 539.8 & 9.4 & 5.28 & 0.27 & 194.2 & 17.6 & 368.7 & 8.5 & 4.21 & 0.22 & 222.5 & 30.9 & 532.1 & 14.1 & 7.07 & 0.31 \\
\hline & P22: $T y$ & Haplustep & as- Sura & a, Rain & Desi) & & & & & & & & & & & & & \\
\hline $0-15$ & 250.9 & 30.5 & 713.8 & 15.7 & 8.73 & \begin{tabular}{|l|}
0.40 \\
\end{tabular} & & & & & & & & & & & & \\
\hline $15-30$ & 209.0 & 30.0 & 630.3 & 14.8 & 9.27 & 0.31 & & & & & & & & & & & & \\
\hline $30-60$ & 201.6 & 25.4 & 455.9 & 13.9 & 5.45 & \begin{tabular}{|l|}
0.36 \\
\end{tabular} & & & & & & & & & & & & \\
\hline $60-90$ & 185.9 & 26.4 & 487.4 & 11.6 & 6.64 & \begin{tabular}{|l|}
0.15 \\
\end{tabular} & & & & & & & & & & & & \\
\hline $90-120$ & 145.2 & 20.4 & 284.0 & 8.8 & 4.21 & \begin{tabular}{|l|}
0.09 \\
\end{tabular} & & & & & & & & & & & & \\
\hline Min & 145.2 & 20.4 & 284.0 & 8.8 & 4.21 & 0.09 & & & & & & & & & & & & \\
\hline Max & 250.9 & \begin{tabular}{|l|}
30.5 \\
\end{tabular} & $\begin{array}{l}713.8 \\
\end{array}$ & 15.7 & 9.27 & 0.40 & & & & & & & & & & & & \\
\hline Mean & 198.5 & 26.5 & 514.3 & 12.9 & 6.86 & 0.26 & & & & & & & & & & & & \\
\hline
\end{tabular}


sources etc in the root rhizosphere as external sources would be another reason for higher available $\mathrm{P}_{2} \mathrm{O}_{5}$ in surface soil.

In case of rainfed profiles (Table 1) i.e. $\mathrm{P} 2, \mathrm{P} 4, \mathrm{P} 6$, P8, P10, P12, P14, P16, P18, P20 and P22, status of the same was 'low to marginally high' and varied widely from 26.1 to $34.5,14.5$ to $32.3,18.6$ to 44.7 , 28.6 to $33.5,18.6$ to $24.8,19.9$ to $57.1,18.6$ to 39.7 , 12.4 to $24.8,15.8$ to $29.8,10.8$ to 22.3 and 20.4 to $30.5 \mathrm{~kg} \mathrm{ha}^{-1}$, respectively, with corresponding mean values of $29.7,26.4,29.8,31.5,21.4,34.3,28.1$, $19.4,23.8,17.6$ and $26.5 \mathrm{~kg} \mathrm{ha}^{-1}$, respectively. However, P12 had the highest $\left(34.3 \mathrm{~kg} \mathrm{ha}^{-1}\right)$ mean available $\mathrm{P}_{2} \mathrm{O}_{5}$ content, while $\mathrm{P} 20$ exhibited the lowest mean $\left(17.6 \mathrm{~kg} \mathrm{ha}^{-1}\right)$ available $\mathrm{P}_{2} \mathrm{O}_{5}$. Based on profile mean available $\mathrm{P}_{2} \mathrm{O}_{5}$ content, the rainfed profiles can be placed in the following descending order: $\mathrm{P} 12>\mathrm{P} 8>\mathrm{P} 6>\mathrm{P} 2>\mathrm{P} 14>\mathrm{P} 22>\mathrm{P} 4>\mathrm{P} 18$ $>\mathrm{P} 10>\mathrm{P} 16>\mathrm{P} 20$. Available $\mathrm{P}_{2} \mathrm{O}_{5}$ decreased with depth in all profiles, except $\mathrm{P} 10, \mathrm{P} 12, \mathrm{P} 14$ and $\mathrm{P} 18$. In all the profiles rating of available $\mathrm{P}_{2} \mathrm{O}_{5}$ was 'low' from surface to lower horizon. Thus, available $\mathrm{P}_{2} \mathrm{O}_{5}$ management in soils with low available $\mathrm{P}_{2} \mathrm{O}_{5}$ status particularly for hybrid / $B t$ cotton would be necessary for improving their productivity and maintain soil quality / health. Application of biocompost / vermicompost / organic matter incombination with PSB and / or inorganic phosphorus with proper placement would be some options for available $\mathrm{P}_{2} \mathrm{O}_{5}$ management in soils. Irrigated profile had higher mean available $\mathrm{P}_{2} \mathrm{O}_{5}$ $\left(31.2 \mathrm{~kg} \mathrm{ha}^{-1}\right)$ status as compared to that of rainfed profiles $\left(26.2 \mathrm{~kg} \mathrm{ha}^{-1}\right)$ which might be due to the higher degree of P-fixation with $\mathrm{Ca}$ under comparatively higher $\mathrm{pH}$ in rainfed situation.

This apart, higher application of mineral $\mathrm{P}$ fertilizer in irrigated soils showing more available $\mathrm{P}_{2} \mathrm{O}_{5}$ might be another reason. Prabhavati et al. (2015) found that all soils were low in available $\mathrm{P}$ due to its fixation due by $\mathrm{CaCO}_{3}$. Kumar (2017) that available $\mathrm{P}_{2} \mathrm{O}_{5}$ varied respectively from 15.4 to 59.5 $\mathrm{kg} \mathrm{ha}^{-1}$ (low to marginally high) in irrigated pedons, while the corresponding values of rainfed pedons were, 12.1 to $50.2 \mathrm{~kg} \mathrm{ha}^{-1}$ (low to medium). All the irrigated pedons showed higher mean available $\mathrm{P}_{2} \mathrm{O}_{5}$ status as compared to respective rainfed pedons perhaps due to more organic matter, better crop management practices inclusive of fertilizer application.

\section{Available potassium $\left(\mathrm{K}_{2} \mathrm{O}\right)$}

Available $\mathrm{K} 2 \mathrm{O}$ from all soil depths of irrigated profiles presented in Table 1 revealed that the available $\mathrm{K} 2 \mathrm{O}$ in P1, P3, P5, P7, P9, P11, P13, P15, P17, P19 and P21, though varied widely, yet was rated 'medium to very high' in all depths. However, mean available $\mathrm{K} 2 \mathrm{O}$ values in above profiles were 987.0, 702.1, 835.5, 720.2, 752.4, 607.5, 507.1, $444.2,447.3, \quad 539.8$ and $532.1 \mathrm{~kg} \mathrm{ha}{ }^{-1}$, in chronological order. Similarly, in rainfed profiles of P2, P4, P6, P8, P10, P12, P14, P16, P18, P20 and $\mathrm{P} 22$, the mean available $\mathrm{K}_{2} \mathrm{O}$ values were 972.3 , $670.0,830.9,603.1,653.9,604.4,505.8,435.9$, $421.7,368.7$ and $514.3 \mathrm{~kg} \mathrm{ha}^{-1}$, respectively (Table 1). It was noticed that the available $\mathrm{K}_{2} \mathrm{O}$ did not follow any definite pattern with depth in both irrigated and rainfed profiles. However, based on profile mean available $\mathrm{K}_{2} \mathrm{O}$, the irrigated profiles can be placed in the following descending order: P1 $>$ P5 > P4 > P7 > P3 > P11 > P19 > P21 > P13> $\mathrm{P} 17>\mathrm{P} 5$, while rainfed profiles can be placed in the following descending order: P2 $>$ P6 $>$ P4 $>$ $\mathrm{P} 10>\mathrm{P} 12>\mathrm{P} 8>\mathrm{P} 22>\mathrm{P} 14>\mathrm{P} 16>\mathrm{P} 18>\mathrm{P} 20$. The reason for 'high' status of available $\mathrm{K}_{2} \mathrm{O}$ content in these soils might be the presence of high quantity of micaceous (biotite and muscovite) clay minerals which released $\mathrm{K}$ by dissolution process under sodic soil condition. Similar reasons for high available $\mathrm{K}_{2} \mathrm{O}$ in soils were earlier reported by Singh and Mishra, (2012). Higher range of available $\mathrm{K}_{2} \mathrm{O}$ was noticed in cotton growing soils by Bhaskar (2015). However, mean available $\mathrm{K}_{2} \mathrm{O}$ of irrigated profiles was higher $\left(643.2 \mathrm{~kg} \mathrm{ha}^{-1}\right)$ as compared to that of rainfed profiles $\left(598.3 \mathrm{~kg} \mathrm{ha}^{-1}\right)$ which might be due to higher solublization of potassium under irrigated condition from mineral lattice. Sharma, et al. (2008) and Kumar (2017) found that $\mathrm{K}_{2} \mathrm{O}$ ranged from $134-573 \mathrm{~kg} \mathrm{ha}^{-1}$ and most of the samples classified under low category due to the intensive cropping systems and removal of nutrients is more as compared to addition which create negative balance of nutrients in soil. In addition to this, the imbalanced use of fertilizers and inadequate use of organic manure are also responsible for increasing deficiency of available nutrients in these soils.

Available sulphur (S)

Available $S$ from all depths of profiles (irrigated and rainfed) are presented in Table 1. Status of available $\mathrm{S}$ in irrigated profiles i.e. P1, P3, P5, P7, 
P9, P11, P13, P15, P17, P19 and P21, showed 'low to marginally high' and varied widely from 11.6 to $20.1,9.2$ to $15.1,8.9$ to $15.9,8.1$ to $14.6,7.7$ to $14.9,7.7$ to $18.1,6.9$ to $11.2,6.5$ to $13.2,8.8$ to $10.2,7.8$ to 10.9 and 9.5 to $19.7 \mathrm{ppm}$, respectively, with corresponding mean values of $16.5,11.7,12.5$, $12.0,12.3,13.3,9.3,10.9,9.6,9.4$ and $14.1 \mathrm{ppm}$, respectively. The magnitude of available $S$ content decreased with depth (except in P1, P3, P7, P11 and $\mathrm{P} 19$ as a result of churning processes of vertic clay / black soils) due to decreased quantum of organic matter at lower depths and leaching of sulphur by percolating water. Available $\mathrm{S}$ in surface soil of profiles contained 20.1, 15.1, 15.9, 14.3, 14.9, 18.1, $11.2,13.2,10.2,10.9$ and $19.7 \mathrm{ppm}$, respectively showing 'moderately high' available S status in P1 and rest of the profiles showed 'medium' status. Based on profile mean available $\mathrm{S}$ content, the irrigated profiles can be arranged in the following descending order: $\mathrm{P} 1>\mathrm{P} 21>\mathrm{P} 11>\mathrm{P} 5>\mathrm{P} 9>\mathrm{P} 7>$ $\mathrm{P} 3>\mathrm{P} 15>\mathrm{P} 17>\mathrm{P} 19>\mathrm{P} 13$. However, mean available $\mathrm{S}$ content of soil up to $60 \mathrm{~cm}$ depth was found 'moderately medium', particularly in Bharuch district areas of Maktampur and nearby villages (Bharuch, Kasakpati, Kanbivaga and Jhadeshwar), Achhaliya and nearby villages (Vaghpara and Umalla), Tancha (villages of Samni and Kalak), Vagra and nearby villages (Gandhar, Vagra, Muler, Aladar and Trankal), Manglad and nearby villages (Mahapara and Kundhal), Hansot and nearby villages (Vamleshwar and Katpor), indicating 'medium' productivity potential of cotton, S management would be required which is possible by application of at higher addition of organic amendments (manures, FYM, biocompost etc.) to adequate $\mathrm{S}$ uptake and ultimately improved growth and yield of cotton crop as reported by Winans et al. (2015).

In case of rainfed profiles (Table 1) i.e. $\mathrm{P} 2, \mathrm{P} 4, \mathrm{P} 6$, P8, P10, P12, P14, P16, P18, P20 and P22, status of the same was 'low to medium' status exhibiting 7.2 to $18.7,8.7$ to $13.1,5.8$ to $15.7,6.2$ to $14.2,7.3$ to $13.1,6.5$ to $14.9,8.9$ to $10.2,7.9$ to $10.1,6.4$ to 9.8 , 6.7 to 10.8 and 8.8 to $15.7 \mathrm{ppm}$, respectively with corresponding mean values of $14.8,10.6,11.6$, $10.6,10.8,11.4,9.8,9.2,8.6,8.5$ and $12.9 \mathrm{ppm}$, respectively. The magnitude of available $S$ content decreased with depth except P2, P4, P8, P10, P14 and P22. Surface soil contained 18.7, 13.1, 15.7,
$14.2,12.6,14.9,10.2,10.1,9.8,10.8$ and $15.7 \mathrm{ppm}$ available $\mathrm{S}$ in 'low to medium' status in all the above profiles in chronological order, showing P2 the highest available $\mathrm{S}$ content $(18.7 \mathrm{ppm})$, while the lowest $(9.8 \mathrm{ppm})$ was found in P16. Based on profile mean available $\mathrm{S}$, the rainfed profiles can be placed in the following descending order: $\mathrm{P} 2>\mathrm{P} 22$ $>\mathrm{P} 6>\mathrm{P} 12>\mathrm{P} 10>\mathrm{P} 4>\mathrm{P} 8>\mathrm{P} 14>\mathrm{P} 16>\mathrm{P} 18>$ P20. Soil up to $60 \mathrm{~cm}$ depth was found 'lower medium' status in rainfed profiles of Bharuch district (Bharuch, Jhagadia, Amod, Gandhar, Jambusar and Hansot) and overcome the 'lower medium' available S status, S-management would be required which is possible by different means as stated above. However, 'low' status was found in Nandod (around of Amletha, Kumasgam, Dholar and Ringni) in Narmada taluka, Dadiapada (around of Dhanor, Soliya and Pangam), Panch Pipri (around of Navagam, Ghodmung, Pat and Selamba) in Sagbara taluka and Tilakwada (around Marundhiya and Gamod) in soil depth up to $60 \mathrm{~cm}$ was perhaps due to low organic carbon content in soils coupled with its low mineralization rate. To overcome the 'low' available S status i.e low crop productivity potential, through addition of inorganic $S$ (especially gypsum) and organic sources like manures, FYM, sulphonated compost, biocompost (an easily available cheap source obtained from sugar factories of South Gujarat as byproduct) and sulphur - solubilising microbes are some of suggested measures in order to sustain soil quality and for possible improvement of cotton yield. In the present investigation, irrigated profiles had the higher available $\mathrm{S}$ content as compared to respective rainfed profile in surface horizon as well as on mean profile basis. The reason might be the higher organic matter content along with mineralization rate in irrigated soils as compared to rainfed soils. Kumar et al. (2016) investigated that, available sulphur to be 'low to high' status and it ranged from 3.8 to 74.8 and 4.5 to $26.2 \mathrm{ppm}$, respectively in irrigated and rainfed soils, while in sub-surface layer their magnitude was lower for both the system. Such wide range of available sulphur in these cotton soils might be attributed to variation in soil properties like $\mathrm{pH}, \mathrm{SOC}, \mathrm{CEC}$, addition of varying quantum of organics and variation in agronomic practices. The higher available $\mathrm{S}$ in irrigated soils might be the higher 
organic matter in irrigated soils as compared to rainfed soils.

\section{Available DTPA-Fe}

Results of DTPA-extractable (available) Fe and Zn of different depths of profile soils are presented in Table 1. The results revealed that the status of DTPA- Fe in all depths of irrigated and rainfed profiles ranged from 'low to high'. In case of irrigated profiles i.e. in P1, P3, P5, P7, P9, P11, P13, P15, P17, P19 and P21 respectively from Maktampur, Achhaliya, Tancha, Vagra, Manglad, Hansot, Narmada, Nighat, Sagbara, Uchad and Athwa, DTPA- Fe varied from 7.14 to $9.12,4.58$ to $9.41,4.31$ to $10.42,2.47$ to $8.10,5.20$ to $8.54,7.62$ to $9.81,4.31$ to $7.89,4.01$ to $8.59,3.50$ to $7.61,4.12$ to 9.40 and 4.02 to $10.25 \mathrm{mg} \mathrm{kg}^{-1}$, respectively with corresponding mean values of $8.32,7.22,7.31$, 5.31, 6.60, 8.87, 6.11, 5.21, 5.49, 5.28 and $7.07 \mathrm{mg}$ $\mathrm{kg}^{-1}$, respectively. Only in two profiles (P5 and P21) surface soil recorded 'marginally high' status of DTPA- Fe, but in rest nine irrigated profiles status of the same was 'medium'. However, surface soil of all the profiles recorded the highest value and the magnitude dwindled regularly with increase in soil depth in profiles P7, P13 and P17 and in rest of the profiles the value decreased with irregular trend down the profiles. Such distributions of DTPA- Fe in profile soil might be attributable to soil $\mathrm{pH}$ and texture and also to organic matter content at different depth. At lower depths mainly due to high alkaline $\mathrm{pH}$ the available Fe content was comparatively 'low'. Similar reasons were put forwarded by Prabhavati et al. (2015) for black soils. They found that DTPA extractable Fe content of entire micro-watershed soils was low in soils (Lindsay and Norvell, 1978). However, up to $60 \mathrm{~cm}$ depth (maximum root zone depth of cotton crop) the mean available Fe content of P7 (around Sachan and Pisad area of Vagra taluka), P15 (around Barmba and Zarnawadi area of Nighat, Dadiapada taluka), P17 (around Pankhala, Moravi and Kankhadi from Sagbara taluka) and P19 (around Navapura, Dabhed and Dhanikhod areas of Uchad, Tilakwada taluka) was found 'low' status or 'deficient', indicating that cotton plant might face problem in fulfilling its iron demand from soil. Thus, Fe management would be required and appropriate measures must be taken to improve the status of Fe for these soils through application of more organic matter/ manure, humus etc. as well as inorganic Fe- fertilizers $\left(\mathrm{FeSO}_{4}\right.$ or Fe-chelates). Up to the maximum root zone depth of cotton crop 60 $\mathrm{cm}$ depth the mean available Fe with 'medium' status was observed at Maktampur and nearby villages (Kasakpati, Kanbivaga and Jhadeshwar) of Bharuch taluka, Achhaliya and nearby villages (Vaghpara and Umalla) of Jhagadia taluka, Tancha and nearby villages (Samni and Kalak) of Amod taluka, Manglad and nearby villages (Mahapara and Kundhal) of Jambusar taluka, Hansot and nearby villages (Vamleshwar and Katpor) of Hansot taluka and Narmada city area its surrounding villages (Handi and Dhochki). With respect to profile mean Fe, profiles can be arranged: $\mathrm{P} 11>\mathrm{P} 1>\mathrm{P} 5>\mathrm{P} 3>$ $\mathrm{P} 21>\mathrm{P} 9>\mathrm{P} 13>\mathrm{P} 17>\mathrm{P} 7>\mathrm{P} 19>\mathrm{P} 15$. In case of rainfed profiles DTPA- Fe status ranged from 'low to medium' showing 5.92 to $7.95,3.82$ to $6.45,3.95$ to $9.10,2.89$ to $7.12,3.90$ to $7.01,3.57$ to $9.50,3.18$ to $5.50,2.66$ to $4.71,3.40$ to $6.26,1.63$ to 5.50 and 4.21 to $9.27 \mathrm{mg} \mathrm{kg}^{-1}$, respectively in P2, P4, P6, P8, P10, P12, P14, P16, P18, P20 and P22, respectively from Bharuch, Jhagadia, Amod, Gandhar, Jambusar, Hansot, Nandod, Dadiapada, Panch Pipri, Tilakwada and Panas with corresponding mean values of $7.07,4.97,6.71,4.88,5.77,6.18$, $4.88,4.21,5.19,4.21$ and $6.86 \mathrm{mg} \mathrm{kg}^{-1}$, respectively (Table 1). Surface soils of profiles recorded 'medium' status of DTPA- Fe, while at lower depths mainly due to high alkaline $\mathrm{pH}$ the content of Fe was comparatively 'low'. In P6, P8 and P12, DTPA-Fe gradually diminished with depth and in others trend was irregular with soil depth. However, mean available $\mathrm{Fe}$ up to maximum root zone depth $(60 \mathrm{~cm})$ in seven profiles (P2, P4, P6, P10, P12, $\mathrm{P} 18$ and P22) was found 'marginally medium', while the same in rest of the profiles was 'low'. The area with low mean $\mathrm{Fe}$ was spreaded over in Narmada city areas and Tilakwada, Sagbara and Dadiapada talukas. Thus, precautionary measures as above also should be taken for soils with 'low' status of available Fe. However, profiles in descending order of mean DTPA-Fe were as: P2 > $\mathrm{P} 22>\mathrm{P} 6>\mathrm{P} 12>\mathrm{P} 10>\mathrm{P} 18>\mathrm{P} 4>\mathrm{P} 8>\mathrm{P} 14>$ $\mathrm{P} 16>\mathrm{P} 20$.

\section{Available DTPA-Zinc}

Status of DTPA-extractable (available) $\mathrm{Zn}$ at different soil depths of irrigated profiles varied from 'low to medium' (Table 1). DTPA- Zn varied from 0.21 to $0.51,0.18$ to $0.56,0.14$ to $0.46,0.12$ to $0.45,0.10$ to $0.61,0.12$ to $0.55,0.14$ to $0.42,0.06$ to 
$0.45,0.07$ to $0.40,0.11$ to 0.48 and 0.07 to $0.51 \mathrm{mg}$ $\mathrm{kg}^{-1}$, respectively with corresponding mean values of $0.36,0.38,0.33,0.30,0.32,0.35,0.27,0.25$, $0.23,0.27$ and $0.31 \mathrm{mg} \mathrm{kg}^{-1}$, respectively in P1 to P21 (only odd numbers). However, in case of rainfed profiles (Table 1), the status of DTPA- Zn was 'low' all through (100\%) ranging from 0.19 to $0.48,0.17$ to $0.43,0.11$ to $0.41,0.13$ to $0.43,0.11$ to $0.41,0.08$ to $0.42,0.12$ to $0.40,0.08$ to $0.43,0.12$ to $0.35,0.08$ to 0.44 and 0.09 to $0.40 \mathrm{mg} \mathrm{kg}^{-1}$, respectively in the even number of profiles ( $\mathrm{P} 2$ to P22) with corresponding mean values of $0.34,0.30$, $0.29,0.28,0.28,0.27,0.25,0.23,0.21,0.22$ and $0.26 \mathrm{mg} \mathrm{kg}^{-1}$, respectively. Based on profile mean DTPA- $\mathrm{Zn}$, the irrigated profiles can be placed in the following order: P3 $>$ P1 $>$ P11 $>$ P5 $>$ P9 $>$ P21 $>$ P7 $>$ P13 $>$ P19 $>$ P15 $>$ P7, while, the order for rainfed profiles: $\mathrm{P} 2>\mathrm{P} 4>\mathrm{P} 6>\mathrm{P} 10>\mathrm{P} 8>\mathrm{P} 12$ $>\mathrm{P} 22>\mathrm{P} 14>\mathrm{P} 16>\mathrm{P} 18>\mathrm{P} 20$. Both in irrigated and rainfed profiles surface soil contained the highest magnitudes of DTPA-Zn and thereafter it decreased regularly with depth only in one irrigated profile (P1) and two rainfed profiles (P8 and P12). However, in rest of the irrigated and rainfed profiles DTPA-Zn dwindled with irregular trend down the depth. The decreased in content of $\mathrm{Zn}$ with depth might be due to its close association with organic carbon which was found to decrease down the profiles. The surface soils of irrigated profiles i.e., $\mathrm{P} 1, \mathrm{P} 3, \mathrm{P} 9, \mathrm{P} 11$ and $\mathrm{P} 21$ exhibited 'marginally medium' status of DTPA-Zn and in other irrigated profiles status of the same in surface as well as sub-surface soils was 'low'. Results were supported by the findings (Table 1) as were evidenced from scattered surface samples from cotton growing soils of 11 talukas of South Gujarat. Deficiency of available $\mathrm{Zn}$ in all the rainfed soils as well as major irrigated soils might cause problem in fulfilling the cotton crop demand for zinc in synthesis of growth hormones and during flowering and boll formation stages which ultimately might cause reduction in cotton crop yield. Thus, available $\mathrm{Zn}$ to be improved by adding higher quantum of gradual addition of more organic matter/ manure, FYM, biocompost, crop residues and green manuring etc. and inorganic sources like Zn-Chelates/ Na-Zn-EDTA etc. to avoid possible deficiency of this micronutrient. The overall results indicated that magnitude of profile mean value of all micronutrients under irrigated situation were higher as compared to those of respective rainfed profiles which might be due higher external addition of organic manures, in situ addition of higher plant debris and root volume and management practices. Higher micronutrients content in surface layers, in general, might be due to their addition of organic matter / plant residues, fertilizers and their association with organic matter in surface soil. In case of deeper layers, content decreased which might be due to the presence of more calcium carbonate at deeper layers which decreased the availability of micronutrients as a result of formation of insoluble hydroxides at higher $\mathrm{pH}$. Results on micronutrients under the present study were in the same line as mentioned by Tagore et al. (2014) in black cotton soils and Chouhan et al. (2012) in medium black soils. Kumar (2017) studied soil available micro nutrients status of Inceptisols and Vertisols under irrigated and rainfed cotton system in Bharuch district, Gujarat. He found that in all irrigated pedons, DTPA-Fe and $\mathrm{Zn}$ content of different soil horizons varied from 1.92 to 9.33 and 0.07 to $0.61 \mathrm{mg} \mathrm{kg}^{-1}$, respectively with corresponding mean values of 4.9 and $0.22 \mathrm{mg} \mathrm{kg}^{-1}$, respectively. In case of all rainfed pedons, the corresponding values varied from 1.68 to 9.33 and 0.06 to $0.29 \mathrm{mg} \mathrm{kg}^{-1}$, respectively with the corresponding mean values of 4.2 and $0.16 \mathrm{mg}$ $\mathrm{kg}^{-1}$, respectively. Pedons mean values of all micronutrients under irrigated situation exhibited higher magnitude as compared to those of respective rainfed pedons. In general, the magnitude of DTPA-micronutrients in both the case decreased with depth with decreasing SOC which acted as chelating agent.

\section{Conclusion}

Available $\mathrm{N}$ of irrigated and rainfed soil profiles varied from 111.4 to 303.2 (low to medium) and 94.7 to $299.8 \mathrm{~kg} \mathrm{ha}^{-1}$ (low to medium), respectively. Available $\mathrm{P}_{2} \mathrm{O}_{5}$ correspondingly varied from 17.1 to 79.4 (low to high) and 10.8 to $57.1 \mathrm{~kg} \mathrm{ha}^{-1}$ (low to marginally high), respectively. In general, available $\mathrm{N}$ slightly decreased with depth. The available $\mathrm{P}_{2} \mathrm{O}_{5}$ was higher in surface soils than sub surfaces. Further, profile mean available $\mathrm{K}_{2} \mathrm{O}$ of irrigated and rainfed situations were rated 'high'. All the irrigated pedons jointly showed higher mean 
available $\mathrm{N}, \mathrm{P}_{2} \mathrm{O}_{5}$ and $\mathrm{K}_{2} \mathrm{O}$ status as compared to respective rainfed pedons. Low status of available $\mathrm{N}$ and $\mathrm{P}_{2} \mathrm{O}_{5}$ in these soils urged for $\mathrm{N} \& \mathrm{P}$ management as one of the prime options for enhancing the yield of cotton crop. In rainfed areas 'low' status of available $\mathrm{S}$ was found in Nandod in Narmada taluka, Dadiapada, Panch Pipri in Sagbara taluka and Tilakwada. This apart, some areas of Bharuch district were found to contain 'marginally medium to moderately medium' status of available

\section{References}

Bhaskar, B. P. (2015). Landscape planning for agridevelopment at regional scale: an example from cotton growing Yavatmal district, Maharashtra, India. Journal of Agriculture and Environment for International Development (JAEID), 109(2), 235-269.

Dokuchaiev, V. V. (1886). Report to the Provisional Zenstvo (local authority) of Nizhnil-Norgorod,No.1, In:Collected writings (Sochineniyer), vol. 4, Acad. Sci. USSR, Moscow 1950.

Jackson, M. L. (1973). Soil chemical analysis prentice, Hall of India private LTD, New Delhi.

Jenny, H. (1941). Factors of soil formation. Mc Grow Hill Publ. New York.

Kumar, M. V., \& Haroon, A. M. (2013). Nutrient Status of Sugarcane Growing Soils of Theni District, Tamil Nadu-a Soil Series Based Study. An Asian journal of soil science, 8(2), 385-389.

Kumar, S. (2017). Physical, chemical and biological characterization of irrigated and rainfed Vertisols from farmers' field of cotton growing area at Bara tract (district Bharuch) (Doctoral dissertation, Soil Science And Agricultural Chemistry, Nm College Of Agriculture, Navsari Agricultural University, Navsari).

Kumar, S., Das, A., \& Chinchmalatpure, A. R. (2016). Soil properties and available sulphur variability under irrigated and rainfed cotton in Bara tract of Bharuch, Gujarat. Principal component analysis of soil properties in assessing erodibility indices in the 277 Northern Brahmaputra plains of Assam, 15(4), 296-301.

Lindsay, W. L., \& Norvell, W. A. (1978). Development of a DTPA soil test for zinc, iron, manganese, and copper. Soil science society of America journal, 42(3), 421-428.
$\mathrm{S}$. Thus, the above areas would require $\mathrm{S}$ management through addition of organic amendments (manures, FYM, bio compost etc.) to fulfil the demand of $\mathrm{S}$ by cotton crop in order to achieve higher yield. Thus, available Fe and $\mathrm{Zn}$ are requiring to be improved by addition of more organic matter/ manure, FYM, bio compost, crop residues and green manuring etc. and inorganic sources to fulfil the demand of cotton crop for possible higher yield.

Narendra, C., Sharma, G. D., Khamparia, R. S., \& Sahu, R. K. (2012). Status of sulphur and micronutrients in medium black soils of Dewas district, Madhya Pradesh. Agropedology, 22(1), 66-68.

Olsen, S. R. (1954). Estimation of available phosphorus in soils by extraction with sodium bicarbonate (No. 939). US Department of Agriculture.

Paramasivan, M., \& Jawahar, D. (2014). Characterization, classification and crop suitability of some black cotton soils of southern Tamil Nadu. Agropedology, 24(1), 111118.

Prabhavati, K., Dasog, G. S., Patil, P. L., Sahrawat, K. L., \& Wani, S. P. (2015). Soil fertility mapping using GIS in three agro-climatic zones of Belgaum district, Karnataka. Journal of the Indian Society of Soil Science, 63(2), 173-180.

Sharma, A. P., Singh, U. V., \& Duhan, B. S. (2008). Studies on fertility status of cotton growing soils of Haryana. Journal of Cotton Research and Development, 22(1), 81-84.

Subbiah, B. V. \& Asija, G. L. (1956). Rapid procedure for the estimation of available nitrogen in soil. Current Sci., (125), 259-260.

Tagore, G. S., Bairagi, G. D., Sharma, R., \& Verma, P. K. (2014). Spatial variability of soil nutrients using geospatial techniques: a case study in soils of sanwer tehsil of Indore district of Madhya Pradesh. The International Archives of Photogrammetry, Remote Sensing and Spatial Information Sciences, 40(8), 1353.

Williams, C. H., \& Steinbergs, A. (1959). Soil sulphur fractions as chemical indices of available sulphur in some Australian soils. Australian Journal of Agricultural Research, 10(3), 340-352. 